\title{
Association of MC4R (rs17782313) with diabetes and cardiovascular disease in Korean men and women
}

\author{
Jae Woong Sull ${ }^{1}$, Gitae Kim ${ }^{1}$ and Sun Ha Jee ${ }^{2^{*}}$ D
}

\begin{abstract}
Background: Diabetes is mostly assessed by the fasting glucose level. Several studies reported that serum fasting glucose levels and cardiovascular disease are associated with MC4R.

Methods: A total of 4294 subjects participated in this study. There were 1810 subjects with cardiovascular disease among the 4294 subjects. We used multivariate linear regression models and multiple logistic regression analysis.

Results: Individuals with the TC/CC genotype had a 1.29-fold higher risk of diabetes than did those with the TT genotype when adjusting for age, sex, and BMI (OR, 1.29; 95\% Cl, 1.04-1.60). For healthy subjects, the association was significant in women $(\mathrm{OR}, 1.99 ; 95 \% \mathrm{Cl}, 1.01-3.93)$. Men with the TC/CC genotype had a 1.21-fold higher risk of cardiovascular disease than did those with the $\Pi$ genotype when adjusting for age, sex, and $\mathrm{BMI}(\mathrm{OR}, 1.21 ; 95 \% \mathrm{Cl}$, 1.04-1.41). The relationship between MC4R and cardiovascular disease was stronger in lean men $(\mathrm{OR}, 1.40 ; 95 \% \mathrm{Cl}$, $1.12-1.74, p=0.0028)$ than in overweight men.
\end{abstract}

Conclusions: This study suggests that the rs 17782313 SNP in MC4R is related to diabetes and the SNP is also associated with cardiovascular disease in lean men.

Keywords: Fasting glucose, MC4R, Polymorphisms

\section{Background}

Diabetes is mainly assessed by the fasting blood-glucose level [1]. Several previous studies reported that the melanocortin-4 receptor (MC4R) (MIM 155541) gene is a candidate as a causal gene for type 2 diabetes $[2,3]$. $M C 4 R$ deficiency is related to monogenic obesity [4]. The MC4R rs17782313 SNP has also been linked with obesity in Europeans and Koreans [5, 6]. The SNP rs17782313 was also associated with diabetes in several studies $[3,7,8]$. In Korea, obesity increases the risk of death from cardiovascular disease [9].

\footnotetext{
* Correspondence: jsunha@yuhs.ac

${ }^{2}$ Department of Epidemiology and Health Promotion, Institute for Health Promotion, Graduate School of Public Health, Yonsei University, Seoul, Korea Full list of author information is available at the end of the article
}

Recent studies have reported that the $M C 4 R$ gene was related to cardiovascular disease $[10,11]$. In this study, we investigated the relationship between diabetes, cardiovascular disease, and the rs17782313 MC4R SNP in Korean men and women. We also evaluated modification of the relationship of $M C 4 R$ and cardiovascular disease by obesity.

\section{Methods \\ Study population}

A total of 4294 subjects were the participants who had general health examinations in Health Promotion Center in University hospitals [12]. The biological samples for DNA extraction were obtained prospectively between 2004 and 2013 as a part of the Korean Cancer Prevention Study-II (KCPS-II) Biobank [13]. There were 1810 
subjects with Cardiovascular Disease (CVD) among the 4294 subjects. The cases were obtained by the NHIC health-insurance reimbursement data. The codes of the International classification of Disease (ICD), 10th Revision (I00-199), were used for the definition of CVD. Because of missing fasting blood-glucose level, body mass index (BMI), and SNP rs17782313 data, 35 subjects were excluded. Therefore, the final subjects included 4259 people, and 1782 subjects among them were Cardiovascular Disease (CVD) patients. Among 1782 Cardiovascular Disease (CVD) patients, 1409 individuals had ischemic heart disease and 868 had stroke. The other 2477 subjects were the healthy subjects. The healthy subjects were defined as subjects who do not have the cardiovascular disease.

\section{Data collection}

Each participant was interviewed using a structured questionnaire to collect their personal history of smoking status (never smoked, ex-smoker or current smoker) and demographic characteristics (age, sex, etc.), and other characteristics such as medical history and any medications. Participants were defined as 'current smokers' if they were smoking currently, 'never smokers' if they had no prior history of smoking and 'ex-smokers' if they had previously smoked but at the time of measurement did not smoke. The weight and height were measured with participants lightly clothed.

Peripheral venous-blood samples taken after a 12-h fast and stored at $-70^{\circ} \mathrm{C}$ were used for the measure of fasting blood sugar (FBS), total cholesterol, triglycerides, and HDL-C. We used a Hitachi-7600 analyzer (Hitachi, Ltd., Tokyo, Japan) for the clinical chemistry assays. Detailed phenotype data were previously described $[12,13]$.

\section{Genotyping assays}

The TaqMan reaction was used for the genotyping of the rs17782313 MC4R gene SNP [14]. Only the SNPs with a concordance rate $>99 \%$ in duplicates and a genotype success rate $>98 \%$ were included.

\section{Statistical analysis}

Data are shown as means \pm standard deviation. PLINK and SAS ver. 9.4 (SAS Institute, Cary, NC, USA) were used for most statistical analyses. The linear regression under the additive genetic model was used to assess the association of MC4R rs17782313 with fasting blood glucose levels considering age and sex as covariates. We also used multiple logistic regression analysis under the recessive model to examine the association of the MC4R rs17782313 with diabetes and cardiovascular disease. Body mass index was divided by the median values. The association between the MC4R SNP, diabetes, and cardiovascular diseases were expressed by Odds ratios
(ORs) with 95\% confidence intervals (CIs). Diabetes was defined as fasting serum glucose $\geq 126 \mathrm{mg} / \mathrm{dL}$ or medication. All statistical tests were two-sided, and $p<0.05$ was used for the statistical significance.

\section{Results}

The mean age in men and in women was 51.9 and 52.7 (Table 1). Diabetes patients were about $8.9 \%$ of the subjects; $37.3 \%$ in men and $3.9 \%$ in women were current smokers of the sample dataset. Cardiovascular disease patients were $44.7 \%$ of men and $35.9 \%$ of women. Table 2 shows the $p$ values from a linear regression model for FBS levels when age and sex were included as covariates. The rs17782313 SNP in the MC4R gene was related to mean FBS level and BMI (effect per allele, $1.542 \mathrm{mg} / \mathrm{dL}$, $p=0.0057$, and $0.227 \mathrm{mg} / \mathrm{dL}, p=0.0018$ ). For healthy individuals, the rs17782313 SNP in the MC4R gene was related to mean FBS level and BMI (effect per allele, $1.477 \mathrm{mg} / \mathrm{dL}, p=0.0205$, and $0.237 \mathrm{mg} / \mathrm{dL}, p=0.0096$ ).

The relationship between diabetes and the $M C 4 R$ gene SNP rs17782313 was examined (Table 3). Individuals with the TC/CC genotype had a 1.29-fold higher risk of diabetes than did those with the TT genotype when adjusting for age, sex, and BMI (OR, 1.29; 95\% CI, 1.041.60). When analyzed by sex, the relationship between $M C 4 R$ and diabetes was significant only for men (OR, 1.33; 95\% CI, 1.04-1.70), not women (OR, 1.10; 95\% CI, $0.70-1.75)$. For healthy subjects, individuals with the TC/CC genotype had a 1.40-fold higher risk of diabetes than did those with the TT genotype when for adjusting age, sex, and BMI (OR, 1.40; 95\% CI, 1.01-1.95).

Table 1 General characteristics of the study population

\begin{tabular}{|c|c|c|c|c|}
\hline \multicolumn{2}{|l|}{ Subjects } & All & Men & Women \\
\hline \multirow{2}{*}{\multicolumn{2}{|c|}{$\mathrm{N}$}} & 4259 & 2896 & 1363 \\
\hline & & Mean $\pm S D$ & Mean \pm SD & Mean \pm SD \\
\hline \multicolumn{2}{|l|}{ Age, year } & $52.2 \pm 10.2$ & $51.9 \pm 10.3$ & $52.7 \pm 10.1$ \\
\hline \multicolumn{2}{|l|}{ Weight, kg } & $67.4 \pm 11.1$ & $71.8 \pm 9.6$ & $58.1 \pm 7.7$ \\
\hline \multicolumn{2}{|c|}{ Body mass index, $\mathrm{kg} / \mathrm{m}^{2}$} & $24.4 \pm 3.0$ & $24.8 \pm 2.7$ & $23.5 \pm 3.2$ \\
\hline \multicolumn{2}{|c|}{$\begin{array}{l}\text { Fasting blood sugar, } \\
\text { mg/Dl }\end{array}$} & $97.0 \pm 22.6$ & $98.8 \pm 24.0$ & $93.1 \pm 18.7$ \\
\hline \multicolumn{2}{|c|}{$\begin{array}{l}\text { Systolic blood pressure, } \\
\mathrm{mmHg}\end{array}$} & $121.9 \pm 14.5$ & $123.3 \pm 13.9$ & $118.9 \pm 15.3$ \\
\hline \multirow{2}{*}{\multicolumn{2}{|c|}{$\begin{array}{l}\text { Diastolic blood pressure, } \\
\mathrm{mmHg}\end{array}$}} & $78.2 \pm 10.8$ & $79.7 \pm 10.6$ & $75.0 \pm 10.5$ \\
\hline & & $\%$ & $\%$ & $\%$ \\
\hline \multirow[t]{2}{*}{ Smoking status } & Ex & 28.4 & 40.1 & 2.4 \\
\hline & Current & 26.9 & 37.3 & 3.9 \\
\hline \multicolumn{2}{|c|}{ Cardiovascular disease } & 41.8 & 44.7 & 35.9 \\
\hline \multicolumn{2}{|l|}{ Diabetes $^{\mathrm{a}}$} & 8.9 & 10.2 & 6.2 \\
\hline \multicolumn{2}{|c|}{ Family history of diabetes } & 14.5 & 14.1 & 15.4 \\
\hline
\end{tabular}

$S D$ standard deviation

a Diabetes was defined as fasting serum glucose $\geq 126 \mathrm{mg} / \mathrm{dL}$ or medication 
Table 2 Association between the rs17782313 single nucleotide polymorphism in the MC4R gene and fasting blood-sugar levels based on a linear regression model

\begin{tabular}{|c|c|c|c|c|c|}
\hline \multirow{3}{*}{ Phenotypes } & \multicolumn{3}{|l|}{ Genotypes } & \multirow{3}{*}{$\begin{array}{l}\text { Effect } \\
(\mathrm{mg} / \mathrm{dL})\end{array}$} & \multirow{3}{*}{$P$-value } \\
\hline & $\pi$ & $\mathrm{TC}$ & CC & & \\
\hline & Mean \pm SD & Mean \pm SD & Mean \pm SD & & \\
\hline All subjects & $(N=2428)$ & $(N=1578)$ & $(N=253)$ & & \\
\hline Fasting blood sugar, mg/dL & $96.0 \pm 21.3$ & $98.6 \pm 24.9$ & $96.5 \pm 18.4$ & 1.542 & $0.0057^{*}$ \\
\hline Body mass index, $\mathrm{kg} / \mathrm{m}^{2}$ & $24.3 \pm 2.9$ & $24.5 \pm 3.0$ & $24.8 \pm 3.2$ & 0.227 & 0.0018 \\
\hline Weight, kg & $67.2 \pm 11.0$ & $67.6 \pm 11.1$ & $68.6 \pm 11.1$ & 0.739 & $0.0010^{*}$ \\
\hline Systolic blood pressure, $\mathrm{mmHg}$ & $121.7 \pm 14.6$ & $122.0 \pm 14.3$ & $122.7 \pm 15.0$ & 0.452 & 0.2032 \\
\hline \multirow[t]{2}{*}{ Diastolic blood pressure, $\mathrm{mmHg}$} & $78.2 \pm 11.0$ & $78.2 \pm 10.4$ & $78.4 \pm 11.2$ & 0.061 & 0.8184 \\
\hline & $\%$ & $\%$ & $\%$ & & \\
\hline Cardiovascular disease & 40.7 & 44.1 & 38.3 & & 0.0543 \\
\hline Diabetes & 8.0 & 10.5 & 7.1 & & 0.0153 \\
\hline Healthy subjects & $(N=1439)$ & $(N=882)$ & $(\mathrm{N}=156)$ & & \\
\hline Fasting blood sugar, mg/dL & $93.6 \pm 18.5$ & $96.3 \pm 22.5$ & $93.7 \pm 13.3$ & 1.477 & $0.0205^{*}$ \\
\hline Body mass index, $\mathrm{kg} / \mathrm{m}^{2}$ & $24.0 \pm 2.9$ & $24.2 \pm 3.0$ & $24.3 \pm 2.6$ & 0.237 & $0.0096^{*}$ \\
\hline Weight, kg & $66.5 \pm 11.2$ & $66.9 \pm 11.5$ & $67.8 \pm 10.6$ & 0.839 & $0.0035^{*}$ \\
\hline Systolic blood pressure, $\mathrm{mmHg}$ & $119.4 \pm 13.5$ & $119.3 \pm 13.3$ & $119.8 \pm 12.1$ & 0.156 & 0.7119 \\
\hline \multirow[t]{2}{*}{ Diastolic blood pressure, $\mathrm{mmHg}$} & $78.8 \pm 10.9$ & $78.5 \pm 10.5$ & $78.8 \pm 10.1$ & -0.039 & 0.9068 \\
\hline & $\%$ & $\%$ & $\%$ & & \\
\hline Diabetes & 5.7 & 8.1 & 5.1 & & 0.0642 \\
\hline
\end{tabular}

Estimated effect size ( $\beta$ ) and $p$ values in the multiple linear regression model considered age and sex in the additive model. $P$ values for cardiovascular disease and diabetes were obtained from chi-square test. * significant of $p<0.05$

However, the association was stronger in women (OR, 1.99; 95\% CI, 1.01-3.93), and the association of MC4R with diabetes was not found in men (OR, 1.24; $95 \% \mathrm{CI}$, $0.85-1.81)$.

The relationship of the $M C 4 R$ gene SNP rs17782313 to cardiovascular disease was also examined (Table 4).
Men with the TC/CC genotype had a 1.21-fold (range, 1.04-1.41-fold) higher risk of cardiovascular disease than did those with the TT genotype when for adjusting age, sex, BMI (OR, 1.21; 95\% CI, 1.04-1.41). In contrast, the relationship of MC4R with cardiovascular disease was not found in women.

Table 3 Odds ratios (OR) of the polymorphic rs17782313 MC4R genotypes for diabetes in the population

\begin{tabular}{|c|c|c|c|c|c|c|c|}
\hline \multirow[b]{3}{*}{ Subjects } & \multirow[b]{3}{*}{ Genotype } & \multirow{3}{*}{$\begin{array}{l}\text { Normal } \\
-N(\%)\end{array}$} & \multicolumn{5}{|l|}{ Diabetes $^{b}$} \\
\hline & & & \multirow[b]{2}{*}{$N(\%)$} & \multicolumn{2}{|l|}{ Model 1} & \multicolumn{2}{|l|}{ Model 2} \\
\hline & & & & $\mathrm{OR}\left(95 \% \mathrm{Cl}^{\mathrm{a}}\right)$ & $P$-value & $\overline{\mathrm{OR}\left(95 \% \mathrm{Cl}^{\mathrm{b}}\right)}$ & $P$-value \\
\hline All & $\pi$ & 2233 (57.6) & $195(51.5)$ & 1.00 (reference) & & 1.00 (reference) & \\
\hline$(n=4259)$ & $\mathrm{TC} / \mathrm{CC}$ & $1647(42.4)$ & $184(48.6)$ & $1.32(1.07-1.64)^{*}$ & 0.0113 & $1.29(1.04-1.60) *$ & 0.0218 \\
\hline \multirow[t]{2}{*}{ Men } & $\pi$ & $1513(58.2)$ & 151 (51.4) & 1.00 (reference) & & 1.00 (reference) & \\
\hline & $\mathrm{TC} / \mathrm{CC}$ & 1089 (41.8) & $143(48.6)$ & $1.34(1.05-1.72) *$ & 0.0182 & $1.33(1.04-1.70) *$ & 0.0219 \\
\hline \multirow[t]{2}{*}{ Women } & $\pi$ & $720(56.3)$ & $44(51.8)$ & 1.00 (reference) & & 1.00 (reference) & \\
\hline & $\mathrm{TC} / \mathrm{CC}$ & $558(43.7)$ & $41(48.2)$ & $1.25(0.80-1.96)$ & 0.3337 & $1.10(0.70-1.75)$ & 0.6878 \\
\hline All Healthy & $\pi$ & 1357 (58.6) & $82(50.9)$ & 1.00 (reference) & & 1.00 (reference) & \\
\hline$(n=2477)$ & $\mathrm{TC} / \mathrm{CC}$ & $959(41.4)$ & $79(49.1)$ & $1.46(1.05-2.02) *$ & 0.0234 & $1.40(1.01-1.95) *$ & 0.0424 \\
\hline \multirow[t]{2}{*}{ Men } & $\pi$ & 887 (59.9) & $67(54.9)$ & 1.00 (reference) & & 1.00 (reference) & \\
\hline & $\mathrm{TC} / \mathrm{CC}$ & $594(40.1)$ & $55(45.1)$ & $1.27(0.88-1.85)$ & 0.2082 & $1.24(0.85-1.81)$ & 0.2580 \\
\hline \multirow[t]{2}{*}{ Women } & $\pi$ & $470(56.3)$ & 15 (38.5) & 1.00 (reference) & & 1.00 (reference) & \\
\hline & $\mathrm{TC} / \mathrm{CC}$ & $365(43.7)$ & $24(61.5)$ & $2.13(1.09-4.19) *$ & 0.0277 & $1.99(1.01-3.93) *$ & 0.0490 \\
\hline
\end{tabular}

Model 1: Adjusted for age and sex. Model 2: Adjusted for age, sex, and body mass index

${ }^{a} \mathrm{Cl}$, confidence interval. ${ }^{\mathrm{b}}$ Diabetes was defined as fasting serum glucose $\geq 126 \mathrm{mg} / \mathrm{dL}$ or medication. ${ }^{*}$ significant of $p<0.05$ 
Table 4 Odds ratios (OR) of the polymorphic rs17782313 MC4R genotypes for cardiovascular disease in the population $(n=4259)$

\begin{tabular}{|c|c|c|c|c|c|c|c|}
\hline \multirow[t]{3}{*}{ Subjects } & \multirow[b]{3}{*}{ Genotype } & \multirow{3}{*}{$\begin{array}{l}\text { Normal } \\
N(\%)\end{array}$} & \multicolumn{5}{|c|}{ Cardiovascular Disease } \\
\hline & & & \multirow[b]{2}{*}{$N(\%)$} & \multicolumn{2}{|l|}{ Model 1} & \multicolumn{2}{|l|}{ Model 2} \\
\hline & & & & OR $\left(95 \% \mathrm{Cl}^{\mathrm{a}}\right)$ & $P$-value & OR (95\% Cl) & $P$-value \\
\hline \multirow[t]{2}{*}{ All } & $\pi$ & $1439(58.1)$ & $989(55.5)$ & 1.00 (reference) & & 1.00 (reference) & \\
\hline & $\mathrm{TC} / \mathrm{CC}$ & $1038(41.9)$ & $793(44.5)$ & $1.13(1.00-1.28)$ & 0.0599 & $1.11(0.98-1.26)$ & 0.1174 \\
\hline \multirow[t]{2}{*}{ Men } & $\pi$ & $954(59.5)$ & $710(54.9)$ & 1.00 (reference) & & 1.00 (reference) & \\
\hline & $\mathrm{TC} / \mathrm{CC}$ & $649(40.5)$ & $583(45.1)$ & $1.22(1.05-1.42)^{*}$ & 0.0096 & $1.21(1.04-1.41)^{*}$ & 0.0144 \\
\hline \multirow[t]{2}{*}{ Women } & $\pi$ & $485(55.5)$ & $279(57.1)$ & 1.00 (reference) & & 1.00 (reference) & \\
\hline & $\mathrm{TC} / \mathrm{CC}$ & $389(44.5)$ & $210(42.9)$ & $0.94(0.75-1.19)$ & 0.5990 & $0.89(0.71-1.13)$ & 0.3474 \\
\hline
\end{tabular}

Model 1: Adjusted for age and sex

Model 2: Adjusted for age, sex, and body mass index

* significant of $p<0.05$

${ }^{a} \mathrm{Cl}$, confidence interval

Table 5 shows the analysis by BMI for men. The relationship between $M C 4 R$ and cardiovascular disease was stronger in men with $\mathrm{BMI}<24.75$ (OR, 1.40; 95\% CI, $1.12-1.74, p=0.0028)$ than in subjects with $\mathrm{BMI}>=24.75$ $(p=0.6461)$. However, the interaction between BMI and $M C 4 R$ (rs17782313) genotype for cardiovascular disease was not significant $(p$ for interaction $=0.0753$ ).

\section{Discussion}

In a cohort of 4259 people, the rs17782313 SNP in the $M C 4 R$ gene was related to serum glucose level, as in previous studies. A meta-analysis of 123,373 individuals reported that the rs17782313 polymorphism in MC4R gene has the BMI independent significant association with risk of type 2 diabetes [7]. A recent study reported a strong association with MC4R loci for type 2 diabetes $(\mathrm{OR}=1.70)$ [2]. Another study reported that the rs17782313 SNP was significantly associated with increased risk of diabetes [3]. A recent study reported that a Mediterranean dietary pattern could influence the relationship between MC4R gene rs17782313 polymorphisms and the risk of type 2 diabetes [8]. In our study for healthy subjects, the association of MC4R gene rs17782313 with diabetes was stronger in women than in men. A study also reported that the allele C of MC4R (rs17782313) was associated with a higher risk of type 2 diabetes mellitus in women [15].
The MC4R gene was associated with BMI and is involved in the regulation of insulin secretion $[5,16]$. Loos et al. [5] in a meta-analysis from European subjects reported a significant association between rs17782313 in the MC4R gene and BMI in adults and children. A study also demonstrated that genetic variants in MC4R affect the obesity phenotype in Koreans [6]. In another metaanalysis, the association of the MC4R gene with insulin resistance and type 2 diabetes was reported even after adjustment for BMI [7]. The MC4R gene (rs17782313 and rs17700633) were related to obesity risk and insulin resistance in two genome-wide association studies $[5,17]$. In this study, we found that the MC4R SNP rs17782313 was associated with BMI and weight.

In this study, the rs17782313 SNP in the MC4R gene was related to cardiovascular disease in men. The association was stronger in lean men than in overweight men. A recent study reported that MC4R gene may contribute the co-occurrence of coronary artery disease and obesity [10]. They reported that the MC4R gene SNPs were associated with coronary artery disease $\left(p<5 \times 10^{-8}\right)$. They also explained that the mechanisms whereby MC4R SNPs contribute to obesity can increase the liability to coronary artery disease. Another study reported that the MC4R showed higher expression in mesenteric fat among obese and diabetic rats then compared with lean rats [18]. In the present study, the mean age in men with $\mathrm{BMI}<24.75$ (52.6 years old) was higher than in men with

Table 5 Odds ratios (OR) of polymorphic rs17782313 MC4R genotypes for cardiovascular disease in Korean men $(n=2896)$

\begin{tabular}{|c|c|c|c|c|c|}
\hline \multirow[b]{2}{*}{ Subjects } & \multirow[b]{2}{*}{ Genotype } & \multirow{2}{*}{$\begin{array}{l}\text { Normal } \\
N(\%)\end{array}$} & \multicolumn{3}{|c|}{ Cardiovascular Disease } \\
\hline & & & $N(\%)$ & $\mathrm{OR}^{a}\left(95 \% \mathrm{Cl}^{\mathrm{b}}\right)$ & $P$-value \\
\hline \multirow[t]{2}{*}{$\mathrm{BMI}<24.75$} & $\pi$ & $516(61.4)$ & $325(53.4)$ & 1.00 (reference) & \\
\hline & $\mathrm{TC} / \mathrm{CC}$ & $325(38.6)$ & $284(46.6)$ & $1.40(1.12-1.74)^{*}$ & 0.0028 \\
\hline \multirow[t]{2}{*}{$\mathrm{BMI}>=24.75$} & $\pi$ & $438(57.5)$ & $385(56.3)$ & 1.00 (reference) & \\
\hline & $\mathrm{TC} / \mathrm{CC}$ & $324(42.5)$ & $299(43.7)$ & $1.05(0.85-1.30)$ & 0.6461 \\
\hline
\end{tabular}

* significant of $p<0.05$

$P$ for the interaction between obesity $(B M I>=24.75)$ and MC4R ( $r$ 17782313) $=0.0753$

${ }^{a}$ Adjusted for age and $\mathrm{BMI}{ }^{\mathrm{b}} \mathrm{Cl}$, confidence interval 
BMI $>=24.75$ (51.3 years old $)(p=0.0012)$. The CVD patients in men with $\mathrm{BMI}<24.75(42.0 \%)$ was smaller than in men with $\mathrm{BMI}>=24.75(47.3 \%) \quad(p=0.0046)$ (Data not shown).

MC4R is localized to chromosome 18q21.3 [19], is highly expressed in the hypothalamus, and is related to appetite and energy control [20]. In mice research, the MC4R gene is associated with hyperinsulinemia before the onset of extreme obesity [21]. Lipocalin-2 crosses the blood brain barrier and binds to MC4R in the paraventricular and ventromedial neurons of the hypothalamus. A recent loss- and gain-of-junction experiment in mice reported that osteoblast-derived lipocalin-2 maintains glucose homeostasis [22]. Another recent study reported that the MC4R gene SNPs influence the body fat content and distribution, as well as relative increase in postprandial carbohydrate utilization [23].

This study has some limitations that need to be discussed. There were the differences in the baseline characteristics including smoking rate, cardiovascular disease, and diabetes prevalence by gender. When we assessed the distribution of the MC4R alleles by gender, the genotype frequency of MC4R gene was similar between men and women (Data not shown). Another limitation is that this study subjects included many CVD patients because the CVD cases were obtained from the KCPS2 dataset $(n=156,701)$ for the case control study design [13]. Therefore, we analyzed the association between diabetes and MC4R gene in the healthy subjects who did not have the cardiovascular disease.

\section{Conclusion}

Asian people may have genetic backgrounds different from those of Western individuals [24]. However, this Korean cohort showed that the rs17782313 SNP in the MC4R gene is related to diabetes and obesity. The SNP was also associated with cardiovascular disease in lean men.

\section{Abbreviations \\ Cl: Confidence intervals; CVD: Cardiovascular disease; FBS: Fasting blood sugar; MC4R: Melanocortin-4 receptor; BMI: Body mass index; ICD: International classification of Disease; OR: Odds ratios; SD: Standard deviation; SNP: Single nucleotide polymorphism}

\section{Acknowledgements}

Not applicable.

\section{Authors' contributions}

Study design: JWS, SHJ. Subjects recruitment and acquisition of data: SHJ. Analysis and interpretation of data: JWS, GK, SHJ. Revision of manuscript content: all authors. Approving final version of manuscript: all authors.

\section{Funding}

This paper was supported by Eulji University in 2018 and funded by the Basic Science Research Program of the National Research Foundation of Korea through the Ministry of Education, Science, and Technology (2018R1D1A1B07050834). The funding body played no role in the design of the study and collection, analysis, and interpretation of data and in writing the manuscript.

\section{Availability of data and materials}

The datasets generated during and/or analyzed during the current study are not publicly available due to data security reasons, i.e., the data contain potentially participant identifying information, but are available from the corresponding author on reasonable request.

\section{Ethics approval and consent to participate}

This study was approved by the Institutional Review Board of Human Research of Yonsei University, and all subjects provided written, informed consent prior to enrollment.

\section{Consent for publication}

Not applicable.

\section{Competing interests}

The authors declare they have no competing interests.

\section{Author details}

${ }^{1}$ Department of Biomedical Laboratory Science, College of Health Sciences, Eulji University, Seongnam, Korea. ${ }^{2}$ Department of Epidemiology and Health Promotion, Institute for Health Promotion, Graduate School of Public Health, Yonsei University, Seoul, Korea.

Received: 16 January 2020 Accepted: 3 August 2020

Published online: 17 August 2020

\section{References}

1. Ogata E, Asahi K, Yamaguchi S, Iseki K, Sato H, Moriyama T, et al. Low fasting plasma glucose level as a predictor of new-onset diabetes mellitus on a large cohort from a Japanese general population. Sci Rep. 2018;8(1): 13927. https://doi.org/10.1038/s41598-018-31744-4.

2. Osman W, Tay GK, Alsafar H. Multiple genetic variations confer risks for obesity and type 2 diabetes mellitus in Arab descendants from UAE. Int J Obes. 2018;42(7):1345-53.

3. Qi L, Kraft P. Hunter DJ, Hu FB. The common obesity variant near MC4R gene is associated with higher intakes of total energy and dietary fat, weight change and diabetes risk in women. Hum Mol Genet. 2008;17(22): $3502-8$

4. Faroogi IS, Keogh JM, Yeo GS, Lank EJ, Cheetham T, O'Rahilly S. Clinical spectrum of obesity and mutations in the melanocortin 4 receptor gene. $\mathrm{N}$ Engl J Med. 2003;348(12):1085-95.

5. Loos RJ, Lindgren CM, Li S, Wheeler E, Zhao JH, Prokopenko I, et al. Common variants near MC4R are associated with fat mass, weight and risk of obesity. Nat Genet. 2008:40(6):768-75.

6. Sull JW, Lee M, Jee SH. Replication of genetic effects of MC4R polymorphisms on body mass index in a Korean population. Endocrine. 2013;44(3):675-9.

7. Xi B, Takeuchi F, Chandak GR, Kato N, Pan HW, AGEN-T2D Consortium, et al. Common polymorphism near the MC4R gene is associated with type 2 diabetes: data from a meta-analysis of 123,373 individuals. Diabetologia. 2012;55(10):2660-6.

8. Koochakpoor G, Hosseini-Esfahani F, Daneshpour MS, Hosseini SA, Mirmiran P. Effect of interactions of polymorphisms in the Melanocortin-4 receptor gene with dietary factors on the risk of obesity and type 2 diabetes: a systematic review. Diabet Med. 2016:33(8):1026-34.

9. Jee SH, Sull JW, Park J, Lee SY, Ohrr H, Guallar E, et al. Body-mass index and mortality in Korean men and women. N Engl J Med. 2006;355(8):779-87.

10. Nikpay M, Turner AW, McPherson R. Partitioning the pleiotropy between coronary artery disease and body mass index reveals the importance of low frequency variants and central nervous system-specific functional elements. Circ Genom Precis Med. 2018;11(2):e002050. https://doi.org/10.1161/ CIRCGEN.117.002050

11. Song Z, Qiu L, Hu Z, Liu J, Liu D, Hou D. Evaluation of the obesity genes FTO and MC4R for contribution to the risk of large artery atherosclerotic stroke in a Chinese population. Obes Facts. 2016;9(5):353-62.

12. Cho ER, Jee YH, Kim SW, Sull JW. Effect of obesity on the association between MYL2 (rs3782889) and high-density lipoprotein cholesterol among Korean men. J Hum Genet. 2016;61(5):405-9.

13. Jee YH, Emberson J, Jung KJ, Lee SJ, Lee S, Back JH, et al. Cohort Profile: The Korean Cancer Prevention Study-II (KCPS-II) Biobank. Int J Epidemiol. 2018; 47(2):385-6f. https://doi.org/10.1093/ije/dyx226. 
14. Hui L, DelMonte T, Ranade K. Genotyping using the TaqMan assay. Curr Protoc Hum Genet. 2008; Chapter 2:Unit 2.10. doi: https://doi.org/10.1002/ 0471142905.hg0210s56.

15. Marcadenti A, Fuchs FD, Matte U, Sperb F, Moreira LB, Fuchs SC. Effects of FTO RS9939906 and MC4R RS17782313 on obesity, type 2 diabetes mellitus and blood pressure in patients with hypertension. Cardiovasc Diabetol. 2013;12:103. https://doi.org/10.1186/1475-2840-12-103.

16. Mansour M, White D, Wernette C, Dennis J, Tao YX, Collins R, et al. Pancreatic neuronal melanocortin-4 receptor modulates serum insulin levels independent of leptin receptor. Endocrine. 2010;37(1):220-30.

17. Chambers JC, Elliott P, Zabaneh D, Zhang W, Li Y, Froguel P, et al. Common genetic variation near MC4R is associated with waist circumference and insulin resistance. Nat Genet. 2008:40(6):716-8.

18. Schmid PM, Heid I, Buechler C, Steege A, Resch M, Birner C, et al. Expression of fourteen novel obesity-related genes in Zucker diabetic fatty rats. Cardiovasc Diabetol. 2012;11:48. https://doi.org/10.1186/1475-2840-11-48.

19. Turki A, Mahjoub T, Mtiraoui N, Abdelhedi M, Frih A, Almawi WY. Association of POL1, MALT1, MC4R, PHLPP and DSEL single nucleotide polymorphisms in chromosome $18 \mathrm{q}$ region with type 2 diabetes in Tunisians. Gene. 2013;527(1):243-7.

20. Walley AJ, Asher JE, Froguel P. The genetic contribution to non-syndromic human obesity. Nat Rev Genet. 2009:10(7):431-42.

21. Huszar D, Lynch CA, Fairchild-Huntress V, Dunmore JH, Fang Q, Berkemeier $L R$, et al. Targeted disruption of the melanocortin-4 receptor results in obesity in mice. Cell. 1997;88(1):131-41.

22. Mosialou I, Shikhel S, Liu JM, Maurizi A, Luo N, He Z, et al. MC4Rdependent suppression of appetite by bone-derived lipocalin 2. Nature. 2017:543(7645):385-90.

23. Adamska-Patruno E, Goscik J, Czajkowski P, Maliszewska K, Ciborowski M, Golonko A, et al. The MC4R genetic variants are associated with lower visceral fat accumulation and higher postprandial relative increase in carbohydrate utilization in humans. Eur J Nutr. 2019;58(7):2929-41.

24. Sung HJ, Jung MK, Eom Y, Lee J, Sull JW, Jee SH. Effects of MTNR1B variants on fasting glucose levels in a Korean population. Genes Genomics. 2012:34:103-6.

\section{Publisher's Note}

Springer Nature remains neutral with regard to jurisdictional claims in published maps and institutional affiliations.

Ready to submit your research? Choose BMC and benefit from:

- fast, convenient online submission

- thorough peer review by experienced researchers in your field

- rapid publication on acceptance

- support for research data, including large and complex data types

- gold Open Access which fosters wider collaboration and increased citations

- maximum visibility for your research: over $100 \mathrm{M}$ website views per year

At $\mathrm{BMC}$, research is always in progress.

Learn more biomedcentral.com/submissions 